\title{
Assessment of Undiscovered Petroleum Resources of the Barents Sea Shelf
}

\begin{abstract}
Four geologic provinces of the Barents Sea Shelf were assessed for undiscovered crude oil, natural gas, and natural gas liquid or condensate resources as part of the U.S. Geological Survey's Circum-Arctic Oil and Gas Resource Appraisal. Using a geology-based methodology, the mean undiscovered, conventional, technically recoverable petroleum resources in the Barents Sea Shelf are estimated to be more than 76 billion barrels of oil equivalent, which includes approximately 11 billion barrels of crude oil, 380 trillion cubic feet of natural gas, and 2 billion barrels of natural gas liquids.
\end{abstract}

\section{Introduction}

In 2008, the U.S. Geological Survey (USGS) completed an assessment of potential undiscovered, technically recoverable crude oil, natural gas, and natural gas liquid resources in the Barents Sea Shelf. These resources are assumed to be recoverable regardless of the presence of sea ice or depth of water. As with other areas assessed in the USGS Circum-Arctic Oil and Gas Resource Appraisal, this area shares important characteristics with many Arctic basins, such as sparse data, high geologic uncertainty, substantial petroleum-resource potential, and technical barriers that impede exploration and development. The Barents Sea Shelf, which lies entirely north of the Arctic Circle, contains an area of approximately 1,760,000 square kilometers between longs $0^{\circ}$ and $80^{\circ} \mathrm{E}$. Most of this area offshore northern Norway and the Russian Federation lies under less than 500 meters of water.

\section{Assessment Units}

The Barents Sea Shelf contains several sedimentary basins separated by structural arches in the eastern part and a broad structural platform in the western part. The shelf was divided into four geologic provinces based on structural style-East Barents Basins Province, Novaya Zemlya Basins and Admiralty Arch Province, Barents Platform Province, and Norwegian Margin Province (fig. 1). The provinces were subdivided into eight geologically distinctive assessment units (AUs) - the Kolguyev Terrace, South Barents Basin and Ludlov Saddle, North Barents Basin, Novaya Zemlya Basins and Admiralty Arch, Barents Platform North, Barents Platform South, Western Barents Margin, and Arctic Norwegian Sea AUs (fig. 1). The Novaya Zemlya Basins and Admiralty Arch AU, although defined, was not quantitatively assessed because of a less than 10 percent probability of the existence of one undiscovered accumulation exceeding the defined minimum size of 50 million barrels of oil equivalent.

\section{Petroleum System Elements}

Analyses of petroleum and rocks from wells indicate sources of petroleum in Middle Triassic and Upper Jurassic mudstones, with possible contributions from underlying Paleozoic and other Mesozoic rocks. Because of possible mixing of petroleum, a single Paleozoic-Mesozoic Composite Total Petroleum System (TPS) was identified for the East Barents Basins, Novaya Zemlya Basins and Admiralty Arch, and Barents Platform Provinces. Along the west margin of the shelf, source rocks include Jurassic, Cretaceous, and possibly Paleogene mudstones, so a single Mesozoic-Cenozoic Composite TPS was identified for the Norwegian Margin Province.

Known reservoir rocks include Carboniferous to Permian, Triassic, Middle and Upper Jurassic, and Cretaceous and Paleogene sandstones, as well as Upper Permian spiculite. Potential reservoirs include upper Paleozoic carbonate rocks.

Known and inferred traps include structural highs with closures, fault-related structures, drapes over structures, stratigraphic onlaps and pinchouts along basin margins, carbonateshelf and reef-associated deposits, stratigraphic traps (for example, submarine fans and channels), and salt structures. Traps formed before and during petroleum generation.

\section{Resource Summary}

The USGS assessed undiscovered conventional, technically recoverable petroleum (discovered reserves not included), resulting in the estimated mean volumes of a probability distribution of approximately 11 billion barrels (1,750 million cubic meters, equivalent to 1,500 million metric tons) of crude oil, 380 trillion cubic feet (11 trillion cubic meters) of natural gas, and 2 billion barrels ( 320 million cubic meters, equivalent to 270 million metric tons) of natural gas liquids (table 1). Most undiscovered petroleum is estimated to be in the East Barents Basins Province. 


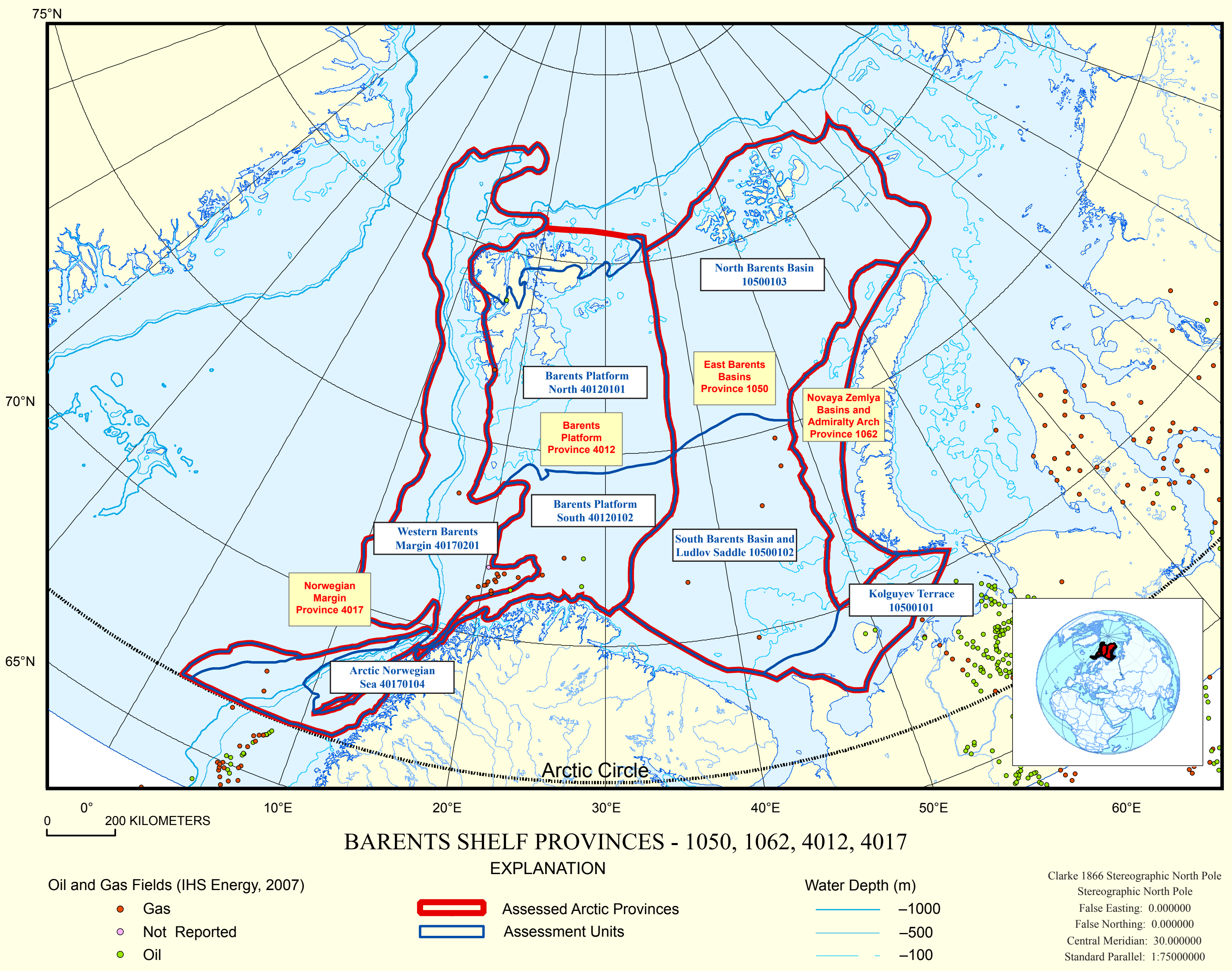

\section{References}

IHS Energy, 2007, International petroleum exploration and able from IHS Energy, 15 Inverness Way East, Englewood, Colorado 80112 USA.

\section{For Further Information}

Assessment results are available at the USGS Central Energy Team website, http://energy.usgs.gov/arctic, or contact Donald L. Gautier, Task Leader for the USGS Circum-Arctic il and Gas Resource Appraisal (gautier@usgs.gov).

Barents Sea Shelf Province Assessment Team: T.R. Klett and Donald L. Gautier (assessing geologists), Kenneth J. Bird, Ronald R. Charpentier, David W. Houseknecht, Thomas Tennyson, and Craig J. Wandrey.

\section{Acknowledgments}

Information and data for the Barents Platform Province and Norwegian Margin were provided by the Norwegian Petroperformed by Feliks Persits. 
Table 1. Assessment results of the East Barents Basins, Novaya Zemlya Basins and Admirality Arch, Barents Platform Provinces, and Western Barents Margin (conventional undiscovered resources).

[MMB, million barrels; BCF, billion cubic feet. Results shown are fully risked estimates. For gas fields, all liquids are included under the natural gas liquids (NGL) category. F95 denotes a 95-percent chance of at least the amount tabulated. Other fractiles are defined similarly. Fractiles are additive under the assumption of perfect positive correlation. TPS, total petroleum system; AU, assessment unit. Gray shading indicates not applicable. Numbers do not exactly add to the totals because totals were calculated by statistical aggregation]

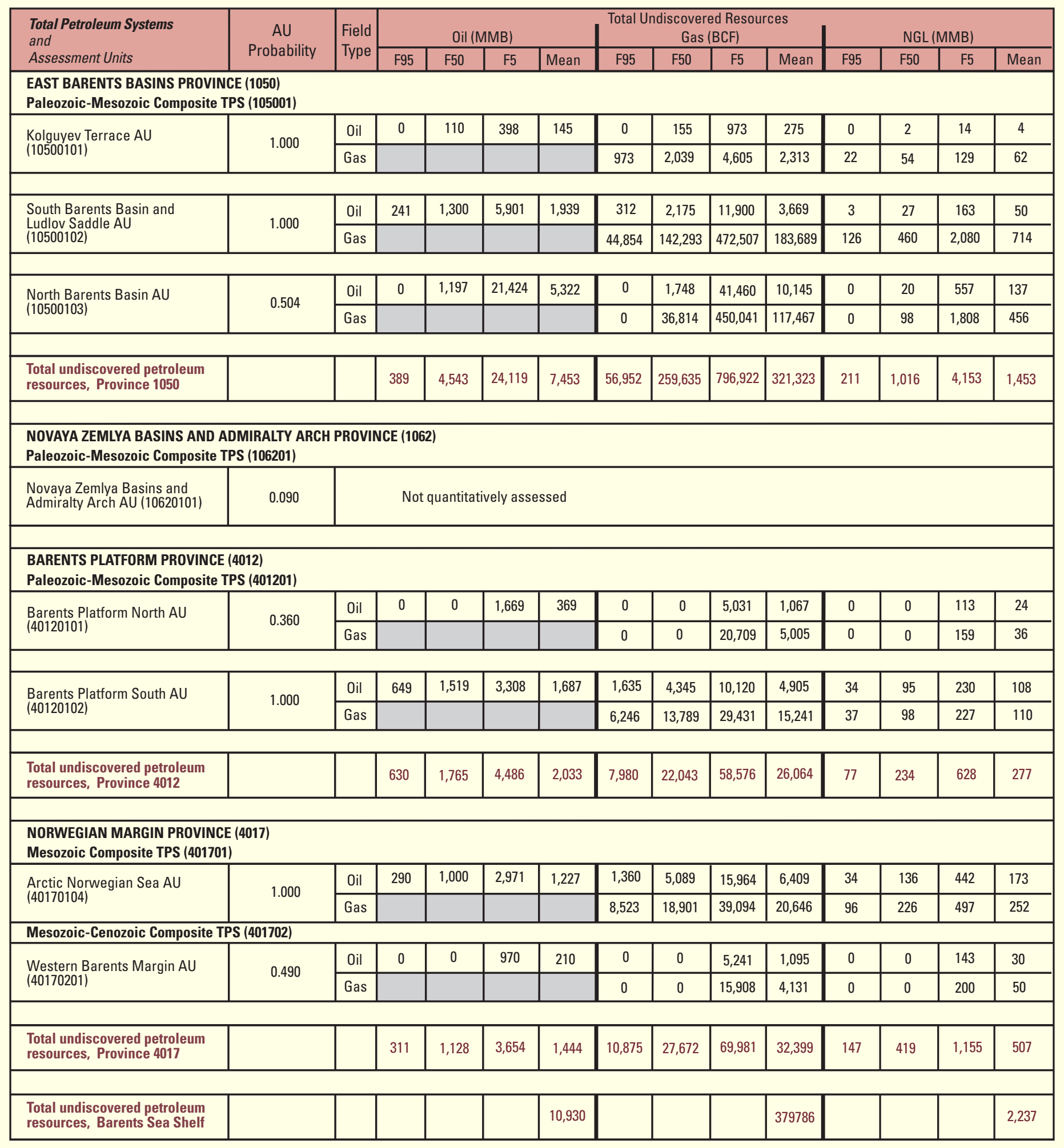

